\title{
THE OCCURRENCE OF APLETODON INCOGNITUS HOFRICHTER ET PATZNER, 1997 (GOBIESOCIDAE) IN THE EASTERN MEDITERRANEAN SEA
}

\author{
Murat BILECENOGLU ${ }^{1 *}$, Murat KAYA ${ }^{2}$ \\ ${ }^{1}$ Department of Biology, Faculty of Arts and Sciences, Adnan Menderes University, Aydin, Turkey \\ 2 Department of Hydrobiology, Faculty of Fisheries, Ege University, Bornova 35100, Izmir, Turkey
}

Bilecenoglu M., Kaya M. 2006. The occurrence of Apletodon incognitus Hofrichter et Patzner, 1997 (Gobiesocidae) in the eastern Mediterranean Sea. Acta Ichthyol. Piscat. 36 (2): 143-145.

\begin{abstract}
A single Apletodon incognitus specimen was collected from Antalya Bay (Levant Sea, Turkey), which is a new record for the eastern Mediterranean fish fauna. The species was previously known only from the Azores (eastern Atlantic) and the western Mediterranean basin. A description of the specimen is presented.
\end{abstract}

Keywords: fish, Gobiesocidae, Apletodon incognitus, cryptobenthic species, eastern Mediterranean

Clingfishes (Gobiesocidae) are small sized cryptobenthic species, which are characterized by a depressed anterior part of the head, scaleless body, and the presence of an adhesive sucking disk on the ventral body surface (Briggs 1955). A total of eight species inhabit the Mediterranean Sea (Quignard and Tomasini 2000), five of which are reported from the eastern basin (Golani et al. 2006).

The genus Apletodon was first described by Briggs (1955), and it currently includes three species and two subspecies, all from the eastern Atlantic and the Mediterranean Sea: A. dentatus dentatus (Facciolà, 1887) (Mediterranean Sea and European coasts of the Atlantic, northwards to Scotland); A. dentatus bacescui (Murgoci, 1940) (south-western Black Sea to the central Black Sea coast of Turkey); A. incognitus Hofrichter et Patzner, 1997 (Azores Islands and western Mediterranean Sea); and A. pellegri$n i$ (Chabanaud, 1925) (eastern Atlantic from Madeira to south Africa) (Briggs 1955, Hofrichter and Patzner 1997, Bat et al. 2006). In the Mediterranean, all these species are rather common within their known distribution range, except for A. dentatus, which is probably the most rare clingfish of the genus (Hofrichter and Patzner 2000).

During macrobenthic surveys carried out along the Levant coasts of Turkey, a single specimen of $A$. incognitus was obtained. This species has not previously been recorded from Turkey (Bilecenoglu et al. 2002) and neither from the eastern Mediterranean Sea (Golani et al. 2006). The presently reported finding considerably extends the distribution range of the species. Morphometric measurements and meristic counts follow the methodology pro- posed by Briggs (1955), and cephalic pore system terminology follows Hofrichter and Patzner (1997). The specimen was fixed in $6 \%$ formalin and deposited in the Zoology Museum of Adnan Menderes University (ZMADU), Turkey. Measurements were made using a $0.1 \mathrm{~mm}$ precision calliper.

Apletodon incognitus Hofrichter et Patzner, 1997 (Fig. 1)

Material examined: ZMADU-P/053, $18 \mathrm{~mm}$ SL ( $22 \mathrm{~mm}$ TL), $0^{\top}$, Kaledran (Antalya Bay), lat $36^{\circ} 06^{\prime} 03^{\prime \prime} \mathrm{N}$, long $32^{\circ} 33^{\prime} 37^{\prime \prime}$ E, 24 August 2005, $2 \mathrm{~m}$ depth, collected from Posidonia oceanica meadows.

Description: Dorsal finrays 4, anal finrays 4, pectoral finrays 21 , caudal finrays 13 . Body oblong, depressed anteriorly and compressed laterally; body depth 6.43 in SL. Head more or less triangular in dorsal outline; head length 2.69 and head width 3.46 , both in SL; head width 1.29 in head length. Snout short and rounded, its length smaller than its width; snout length 3.35 and snout width 3.05 , both in head length. Eyes large, greatest horizontal diameter of eye 3.94 in head length and 0.94 in interorbital distance. Nostrils tubular; posterior nostrils located just above anterior edge of eyes; anterior nostrils about twice as long as posterior nostrils. Caudal peduncle short, its depth 1.00 in its length. Ventral sucking disc length 4.09 in SL. Five rows of flattened papillae in sucking disc region A; six rows in region $\mathrm{B}$; and four rows in region $\mathrm{C}$. Anus surrounded by fleshy papillae, forming noticeable 

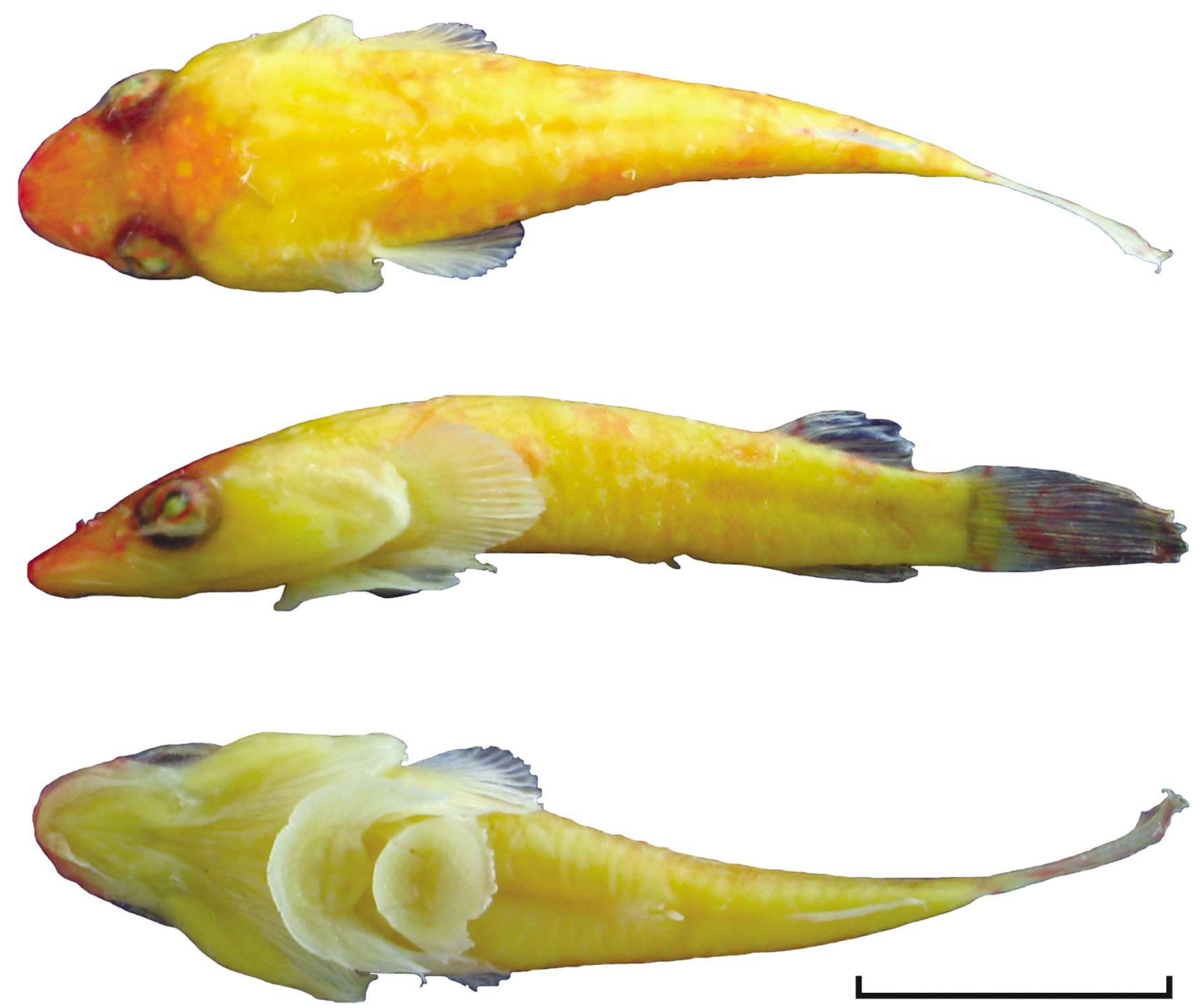

Fig. 1. Dorsal, lateral, and ventral view of Apletodon incognitus Hofrichter et Patzner, 1997, 18 mm SL, collected from Kaledran (Antalya Bay, Turkey), scale bar $=0.5 \mathrm{~cm}$

cluster; anus located well in front of dorsal fin origin and closer to anal fin origin than to rear margin of sucking disk; length of anal fin 1.67 in length between anus and anal fin. Dorsal-caudal distance measured forward not extending to pectoral fin tip; dorsal-caudal distance 2.67 in dorsal fin length. Anal fin origin located under second ray of dorsal fin. Predorsal length 1.26 and postdorsal length 8.18 , both in SL. Upper attachment of gill membrane occurring opposite to 4th pectoral ray and upper attachment of axial dermal flap opposite to 11 th pectoral ray. Lower jaw with two pairs of small incisive teeth projected forwards, followed on each side by one caniniform tooth; upper jaw also with one pair of canine teeth. Cephalic pore system including pairs of three prominent lacrymal pores, two nasal pores, two postorbital pores, three preopercular pores, and three mandibular pores. Fresh specimen dark brown with irregular light spots and pale longitudinal band occurring between eyes. Reddish brown patterns, especially on front of head and sides of body, remaining after fixation.
Remarks: Concerning the Mediterranean Sea, $A$. incognitus can be confused with $A$. dentatus and Diplecogaster bimaculatus (Bonnaterre, 1788), which have similar morphologies and sympatric occurrence. Although several differences were indicated by Hofrichter and Patzner (1997), the simplest way to distinguish Apletodon spp. and D. bimaculatus is the number of lacrymal canal pores (three pores in the former- and two pores in the latter species). Representatives of the genus Apletodon share several common characters, where $A$. incognitus is distinguished from $A$. dentatus by the mandibular canal pores (three in the former species, whereas none in the latter). The eastern Atlantic inhabitant $A$. pellegrini also has three mandibular pores, but it differs from $A$. incognitus by having more pectoral finrays (22-25 vs. 18-22), larger body depth in standard length (5.1-5.2 vs. 5.3-6.7), different structure of anal papillae (distinct vs. less distinct), and relatively higher number of canine teeth in the lower and upper jaws (2-3 vs. 1-2). All counts, measurements, and colour pattern are in agreement with the descriptions made 
by Hofrichter and Patzner (1997), except for the slight difference of eye diameter in interorbital distance value $(0.94$ vs. 1.0-1.5). Morphometric, meristic, and cephalic pore characters of Antalya Bay specimen confirms that this specimen is $A$. incognitus, but not $A$. dentatus or $A$. pellegrini.

Habitat: The study site (Kaledran) is a small cove of Antalya Bay, characterized by dense rocky substrates along the upper infralittoral zone. From a depth of 1.5-2.0 m, patches of Mediterranean tapeweed, Posidonia oceanica, (and lesser Neptune grass, Cymodocea nodosa, to a lesser extend) are observed over fine sand, encircled by rocks covered with two dominant algae, Corallina sp. and Jania rubens. The single $A$. incognitus specimen was collected during a quantitative $P$. oceanica sampling via quadrate frames $(30 \times 30 \mathrm{~cm})$, which also contained the echinoderm, Paracentrotus lividus, and the seagrass clingfish, Opeatogenys gracilis (Canestrini, 1864). Salinity at the sampling site was $39.2 \%$, temperature was $26.9^{\circ} \mathrm{C}$, and dissolved oxygen was $5.52 \mathrm{mg} \cdot \mathrm{L}^{-1}$.

Previous studies have shown that juvenile specimens of $A$. incognitus are generally found in association with echinoderms, and less frequently in $P$. oceanica meadows. Larger specimens prefer empty mussels and stones covered with calcerous algae, also near $P$. oceanica and $C$. nodosa beds, where this species is sympatric with the seagrass clingfish, Opeatogenys gracilis (cf. Hofrichter and Patzner 1997). They can be found at all depths (from $0.2 \mathrm{~m}$ to rarely below $20 \mathrm{~m}$ ) where sea urchins, such as $P$. $l i$ vidus, Arbacia lixula, and Sphaerechinus granularis, are found (Patzner 1999). According to Hofrichter and Patzner (2000), abundance of $A$. incognitus decreases with increasing distance from the seagrass beds. Our habitat observations are in accordance with those available from the western Mediterranean basin.

Distribution: Until now, $A$. incognitus has been reported from the western Mediterranean Sea (southern France: Banyuls-sur-Mer, Baleares: Ibiza, Italy: Elba and Corsica, northern Adriatic: Rovinj and Istria) and the eastern Atlantic (Azores, Madeira, Canary Islands) (Debelius 1997, Hofrichter and Patzner 1997, Gallmetzer et al. 2005). The presently reported Antalya Bay specimen represents the easternmost record of the species in the Mediterranean. Concerning the scarcity of studies on fish assemblages occurring at Posidonia meadows and particularly on the cryptobenthic fishes of the Levant coasts, no enough hard data exists to prove that $A$. incognitus is either an overlooked species, or a neocolonizer. However, its is believed that detailed studies on cryptic fish associated with seagrass beds may reveal a wider distribution range for $A$. incognitus in the eastern Mediterranean basin.
Acknowledgements: We thank to Dr. Melih E. Cinar, for providing the opportunity to collect fish samples during the TUBITAK project No. 104Y065.

\section{REFERENCES}

Bat L., Demirci G.G., Öztürk M. 2006. Occurrence of Apletodon dentatus bacescui (Murgoci, 1940) (Gobiesocidae) and Coryphoblennius galerita (Linnaeus, 1758) (Blenniidae) at the central Black Sea coast of Turkey. Journal of the Black Sea/Mediterranean Environment 12: 59-65.

Bilecenoglu M., Taskavak E., Mater S., Kaya M. 2002. Checklist of the marine fishes of Turkey. Zootaxa 113: 1-194.

Briggs J.C. 1955. A monograph of the clingfishes (order Xenopterygii). Stanford Ichthyological Bulletin 6: $1-224$.

Debelius, H. 1997. Mediterranean and Atlantic fish guide. INAN Unterwasserarchiv, Frankfurt.

Gallmetzer I., Pflugfelder B., Zekely J., Ott J.A. 2005. Macrofauna diversity in Posidonia oceanica detritus: distribution and diversity of mobile macrofauna in shallow sublittoral accumulations of Posidonia oceanica detritus. Marine Biology 147: 517-523.

Golani D., Öztürk B., Basusta N. 2006. Fishes of the eastern Mediterranean. Turkish Marine Research Foundation Publications, Istanbul.

Hofrichter R., Patzner R.A. 1997. A new species of Apletodon from the Mediterranean Sea and the eastern Atlantic with notes on the differentiation between Apletodon and Diplecogaster species (Pisces: Teleostei: Gobiesociformes: Gobiesocidae). Senckenbergiana Biologica 77: 15-22.

Hofrichter R., Patzner R.A. 2000. Habitat and microhabitat of Mediterranean clingfishes (Teleostei: Gobiesociformes: Gobiesocidae). PSZN Marine Ecology 21: 41-53.

Patzner R.A. 1999. Habitat utilization and depth distribution of small cryptobenthic fishes (Blenniidae, Gobiesocidae, Gobiidae, Tripterygiidae) at Ibiza (western Mediterranean Sea). Environmental Biology of Fishes 55 (3): 207-214.

Quignard J.P., Tomasini J.A. 2000. Mediterranean fish biodiversity. Biologia Marina Mediterranea 7 (3): $1-66$.
Received: 14 November 2006

Accepted: 15 January 2007

Published electronically: 15 February 2007 